\title{
Growth of Wheat (Triticum aestivum L.) under Raised Bed Planting Method in Rice-Wheat Cropping System
}

\author{
M I U Mollah¹, MS U Bhuiya², M S Hossain ${ }^{3}$ and S M A Hossain²
}

\begin{abstract}
An experiment was conducted at the Bangladesh Rice Research Institute, Gazipur during Rabi season 200102 and 2002-03 (November to March) to evaluate the effect of raised bed planting method on different crop growth parameters, which influence the wheat productivity. Total tiller production, leaf area index (LAI), dry mater production (DMP), crop growth rate (CGR) and agronomic productivity of wheat under bed planting on 70, 80 and $90 \mathrm{~cm}$ wide beds with two and three plant rows bed ${ }^{-1}$ and conventional method were investigated. The number of tillers $\mathrm{m}^{-2}$ in $70 \mathrm{~cm}$ beds with both two and three rows were statistically identical to conventional method. Wheat plants grown on narrow beds $(70 \mathrm{~cm})$ produced similar LAI to that grown in conventional method but plants in wider beds $(80$ and $90 \mathrm{~cm})$ had less LAI than that in conventional method. Similarly, DMP and CGR in $70 \mathrm{~cm}$ beds were either comparable or higher than conventional method. Grain yield of $70 \mathrm{~cm}$ beds were higher than conventional method. Wheat in $70 \mathrm{~cm}$ beds increased number of panicles $\mathrm{m}^{-2}$, number of grains panicle ${ }^{-1}$ and 1000-grain weight of wheat.
\end{abstract}

Key words: Bed planting, rice-wheat and wheat growth

\section{INTRODUCTION}

Bed planting in rice-wheat cropping system is an alternative tillage and crop establishment method for improving resource use efficiency and increasing the yield frontier (Hobbs et al., 2001). In this system, the land is prepared conventionally and raised bed and furrows are prepared manually or using a raised bed planting machine. Crops are planted in rows on top of the raised beds and irrigation water is applied in the furrows between the beds. Water moves horizontally from the furrows into the beds. This system is often considered for growing high value crops that are more sensitive to temporary water-logging stress. Growing wheat on raised beds though introduced in the Indo-Gangetic Plain few years ago, the practice of rice, the major water-using crop in the rice-wheat cropping system, on narrow raised bed introduced very recently (Connor et al., 2003b). In rice-wheat cropping system, new raised beds are prepared for wheat and after harvesting of wheat, rice is grown in Aman season (Kharif-II) following a required repairing of the beds. An additional advantage of bed planting becomes apparent when beds are permanent, that is, when they are maintained over the medium term and not broken down and reformed for every crop (Hobbs and Gupta, 2003a, Sayre, 2003). In the permanent bed, all the crops of the system, except the first crop in the first year, grown in zero tillage, which cut down the costs of land preparation and bed making, and only repairing cost for bed is needed.

The continuous cultivation of rice and wheat - two crops or more per year - has provided food and livelihoods for millions of rural and urban poor in South Asia. Now a crisis looms as the population is growing at more than $2 \%$ (nearly 24 millions additional mouth to feed) each year and agricultural land area dwindles and yield increase are levelling off (Hobbs, 2003). Increasing food production of this area in the next 20 years to match population growth is challenging. It is made even more difficult because, land area devoted to agriculture will be stagnated or declined and better quality land and water resources is expected to be diverted to other sector of the national economy. In order to grow more food from marginal and good quality lands, the quality of natural resource base must be improved and sustained. Efficiency of natural resources like, seed, water, fuel and labour needs to be improved and that conservation 
technologies like bed planting technology (Hobbs et al., 2001).

Research activities in India and Pakistan showed many advantages of bed planting in rice-wheat systems. The bed planting in ricewheat systems saved $50 \%$ seed and $30-40 \%$ water, increased yield, reduced lodging, facilitated mechanical weeding, offered opportunity for a last irrigation at grain filling stage of wheat, avoided temporary water logging problem, allowed surface basal and top dress fertilizer placement, reduced $\mathrm{N}$ loses and promoted rain water conservation (Moreno et al., 1993, Gupta et al., 2000; Connor et al., 2003a). The soil on the surface of the bed is drier, which is not favourable for weed growth (Malik et al., 1998). Lodging problem is also less on raised bed (Meisner et al., 1992). Additional light enters the canopy and strengthens the straw and soil around the base of the plant. Adoption of bed planting has increased dramatically in the last decade in the high yielding irrigated wheat growing area of northwestern Mexico. It has increased from 6\% in 1981 to $75 \%$ in 1994 due to improved and efficient management of irrigation water; improved fertilizer use efficiency; better weed management; lower seed rate and better plant stands; better drainage and less lodging of wheat (Hobbs and Gupta, 2003a). The research activities on bed planting of wheat so far done and/or reported are mainly on the productivity and resource conservation. Therefore, this study was undertaken to evaluate the effect of bed planting on different crop growth parameters, which influence the agronomic productivity of wheat.

\section{MATERIALS AND METHODS}

The study was carried out at the Bangladesh Rice Research Institute (BRRI), Gazipur during Rabi season 2001-02 and 2002-03 (November to March). The soil of the experimental plot was clay loam with pH6.78. Bed planting in 70, 80 and $90 \mathrm{~cm}$ (center- to-center of furrows) wide bed with two and three plant rows bed ${ }^{-1}$ along with flat (conventional) planting were tested. The experiment was laid out in a randomized complete block design with four replications. The unit plot size was $24 \mathrm{~m}^{2}$. Wheat variety Kanchan was used and seed rate was $120 \mathrm{~kg}^{-1}$. Raised beds and furrows were made manually by spade following the conventional land preparation in the first year. According to the treatments 70,80 and $90 \mathrm{~cm}$ wide beds were made. The height of beds was $15 \mathrm{~cm}$. In the second year, no new beds were made. The beds of the previous year where wheat followed by direct seeded Aman rice were grown kept as permanent bed. It was repaired before seeding of next year's wheat.

Nitrogen, P, K, S and Zn were applied at the rates of $100,36,25,20$ and $4 \mathrm{~kg}^{\mathrm{ha}}{ }^{-1}$, respectively. In the first year, two-thirds $\mathrm{N}$ and whole $\mathrm{P}, \mathrm{K}, \mathrm{S}$ and $\mathrm{Zn}$ fertilizerswere applied at final land preparation. The remaining one-third $\mathrm{N}$ was topdressed at 20 days after sowing (DAS) at crown root initiation (CRI) i.e. three leaf stage. This was followed by irrigation. For the treatments with bed planting, $\mathrm{N}$ was applied on the top of beds only. In the second year, the basal doses of fertilizer were applied at final land preparation in the plots with conventional tillage treatment but in the plots with bed planting treatments, the basal doses were applied before sowing on the top of the beds. Seeds were sown in rows in both bed and conventional methods. For beds, seeds were sown in two and three rows according to the treatments. For conventional method, row-torow distance was $20 \mathrm{~cm}$. In the row, seeds were sown continuously and covered with soil properly. The dates of sowing were 29 and 20 November in the first and second year,respectively. Other recommended crop management practices were followed.

Tiller number, leaf area index (LAI), dry matter production (DMP) and crop growth rate (CGR) were recorded at 10 day intervals starting from 20 DAS. Three sample areas, one square meter each, were marked by bamboo stick in each plot to count total tiller production and panicle number. To measure LAI, from each plot, plant sample of $0.25 \mathrm{~m}^{-2}$ were collected from outside the harvest area excluding border plant rows. Whole sample 
plants were uprooted. Six representative tillers from each sample were removed as sample tillers. Green leaves of sample tillers were removed. The leaf area of sample tillers was measured by using an automatic leaf area meter. Other green leaves from the each sample were removed from the tillers. Then leaves from the sample tillers and leaves from the other tillers of the samples were dried and weighed separately. The LAI was computed by using the method given by Yoshida et al. (1976) as follow:

Leaf area of the sample $=$

Total leaf area of the sample tillers $\left(\mathrm{cm}^{2}\right) \times$ Dry wtof all leaves $(\mathrm{g})$ Dry wtof leaves from sample tillers $(\mathrm{g})$

Where, dry wt of all leaves = dry wt of sample leaves + dry wt of remaining leaves

$$
\mathrm{LAI}=\frac{\text { Leaf area of the sample }\left(\mathrm{cm}^{2}\right)}{\text { Area of land covered by thesample }\left(\mathrm{cm}^{2}\right)}
$$

Dry matter production and CGR were measured from the same samples collected for LAI. The plant samples were dried in an oven at $80^{\circ} \mathrm{C}$ until to reach a constant dry weight. Total dry matter was expressed in $\mathrm{g} \mathrm{m}^{-2}$ and crop growth rate in $\mathrm{g} \mathrm{day}^{-1} \mathrm{~m}^{-2}$. Wheat was harvested on 28 and 21 March in the first and second year, respectively. Grain yield and yield components data were collected at maturity.

\section{RESULTS AND DISCUSSION}

\section{Tiller production}

In the first year, where wheat was sown on new beds, at beginning (20 DAS), the number of tillers $\mathrm{m}^{-2}$ in conventional method was significantly higher than all bed planting treatments and with the progressing of the days from seeding, the differences became reduced and finally no difference was observed between conventional method and bed planting with 70 $\mathrm{cm}$ beds (Table 1). At 30 DAS the tiller production in conventional method was comparable to $70 \mathrm{~cm}$ beds with three plant rows. However, at 40 DAS it was statistically identical to $70 \mathrm{~cm}$ beds with both two and three rows. At 50 DAS the number of tillers $\mathrm{m}^{-2}$ was higher in $70 \mathrm{~cm}$ beds with both two and three rows than conventional method. From 60 to 120 DAS (maturity) the number of tillers $\mathrm{m}^{-2}$ in bed with both two and three rows was statistically similar to conventional method. The number of tillers $\mathrm{m}^{-2}$ was decreased with the increase in bed width with the same plant rows per bed, and three rows per bed produced slightly higher number of tillers $\mathrm{m}^{-2}$ than two rows per bed in the same bed width.

Table 1. Tiller production of wheat under different planting methods at different days after seeding (DAS)

\begin{tabular}{|c|c|c|c|c|c|c|c|c|c|c|c|}
\hline \multirow{2}{*}{ Planting method } & \multicolumn{11}{|c|}{ Tillers $\left(\right.$ no. $\left.\mathrm{m}^{-2}\right)$ at DAS } \\
\hline & 20 & 30 & 40 & 50 & 60 & 70 & 80 & 90 & 100 & 110 & 120 \\
\hline & \multicolumn{11}{|c|}{$2001-02$} \\
\hline $70 \mathrm{~cm}$ bed +2 rows & $148 \mathrm{~cd}$ & $243 \mathrm{~b}$ & $358 \mathrm{a}$ & $363 a$ & $347 a$ & $336 a$ & $329 a$ & $319 a$ & $313 \mathrm{a}$ & $311 \mathrm{a}$ & $309 a$ \\
\hline ows & $159 \mathrm{~b}$ & $246 \mathrm{ab}$ & $350 \mathrm{a}$ & $354 \mathrm{ab}$ & $341 \mathrm{a}$ & 338 a & $336 \mathrm{a}$ & 327 a & 321 a & $319 a$ & $318 \mathrm{a}$ \\
\hline 2 rows & $149 \mathrm{~cd}$ & $224 \mathrm{c}$ & $310 \mathrm{~b}$ & $314 \mathrm{c}$ & $286 \mathrm{~b}$ & $276 \mathrm{~b}$ & $272 \mathrm{~b}$ & $251 \mathrm{~b}$ & $240 c$ & $237 \mathrm{c}$ & $235 c$ \\
\hline 3 rows & $152 \mathrm{bcd}$ & $214 \mathrm{~d}$ & $285 c$ & $289 \mathrm{~d}$ & $273 c$ & $266 \mathrm{bc}$ & $262 b c$ & $255 \mathrm{~b}$ & $252 \mathrm{~b}$ & $249 \mathrm{~d}$ & $248 \mathrm{~b}$ \\
\hline 2 rows & $144 \mathrm{~d}$ & $200 \mathrm{e}$ & $270 \mathrm{~d}$ & $273 \mathrm{e}$ & $257 \mathrm{~d}$ & $249 \mathrm{~d}$ & $244 \mathrm{~d}$ & $232 \mathrm{c}$ & $226 \mathrm{~d}$ & $224 \mathrm{~d}$ & $223 \mathrm{~d}$ \\
\hline 3 rows & $155 \mathrm{bc}$ & $208 \mathrm{~d}$ & $275 \mathrm{~cd}$ & 279 de & $263 \mathrm{~cd}$ & $259 \mathrm{~cd}$ & $256 \mathrm{c}$ & $245 \mathrm{~b}$ & $240 c$ & $237 \mathrm{c}$ & $235 c$ \\
\hline \multirow[t]{2}{*}{ Conventional } & $175 \mathrm{a}$ & $252 \mathrm{a}$ & $349 \mathrm{a}$ & $352 \mathrm{~b}$ & $339 a$ & $334 \mathrm{a}$ & $331 \mathrm{a}$ & 324 a & 321 a & 318 a & $315 \mathrm{a}$ \\
\hline & \multicolumn{11}{|c|}{$2002-03$} \\
\hline 2 rows & $154 \mathrm{a}$ & $259 \mathrm{~b}$ & $354 \mathrm{ab}$ & $359 \mathrm{ab}$ & $346 \mathrm{~b}$ & $332 \mathrm{~b}$ & $322 \mathrm{~b}$ & $317 \mathrm{~b}$ & $312 \mathrm{~b}$ & $311 \mathrm{~b}$ & $310 \mathrm{~b}$ \\
\hline$d+3$ rows & $160 \mathrm{a}$ & $279 \mathrm{a}$ & $360 \mathrm{a}$ & $375 \mathrm{a}$ & $362 \mathrm{a}$ & $354 \mathrm{a}$ & $346 \mathrm{a}$ & $339 a$ & $329 a$ & $328 \mathrm{a}$ & $325 \mathrm{a}$ \\
\hline $80 \mathrm{~cm}$ bed +2 rows & $153 \mathrm{a}$ & $239 c$ & $300 \mathrm{de}$ & $318 \mathrm{~d}$ & $297 \mathrm{~d}$ & $288 \mathrm{~d}$ & $280 \mathrm{~d}$ & $272 \mathrm{~d}$ & $265 \mathrm{~d}$ & $263 \mathrm{~d}$ & $260 \mathrm{~d}$ \\
\hline $\mathrm{ed}+3$ rows & $155 \mathrm{a}$ & $245 \mathrm{bc}$ & $318 \mathrm{~cd}$ & $338 \mathrm{c}$ & $316 c$ & $308 c$ & $301 \mathrm{c}$ & $293 c$ & $286 \mathrm{c}$ & $285 c$ & $282 \mathrm{c}$ \\
\hline $90 \mathrm{~cm}$ bed +2 rows & $153 \mathrm{a}$ & $207 \mathrm{~d}$ & $287 \mathrm{e}$ & $296 \mathrm{e}$ & $268 \mathrm{f}$ & $252 \mathrm{e}$ & $253 \mathrm{e}$ & $248 \mathrm{e}$ & $244 \mathrm{e}$ & $243 \mathrm{e}$ & $241 \mathrm{e}$ \\
\hline$d+3$ rows & $153 \mathrm{a}$ & $215 \mathrm{~d}$ & $335 \mathrm{bc}$ & $352 b c$ & $282 \mathrm{e}$ & $264 \mathrm{e}$ & $254 \mathrm{e}$ & $248 \mathrm{e}$ & $245 \mathrm{e}$ & $243 \mathrm{e}$ & $242 \mathrm{e}$ \\
\hline Conventional & $160 \mathrm{a}$ & $250 \mathrm{bc}$ & $342 \mathrm{ab}$ & $360 a b$ & $325 c$ & $311 \mathrm{c}$ & $300 c$ & $295 c$ & $286 \mathrm{c}$ & $280 \mathrm{c}$ & $274 c$ \\
\hline
\end{tabular}

Figures in a column followed by different letters differ significantly at the $5 \%$ level by DMRT. 
In second year, where wheat was sown in permanent beds, the planting method did not affect the number of tillers $\mathrm{m}^{-2}$ significantly at the beginning (20 DAS) and with the advancement of days, the differences were significant. At $30 \mathrm{DAS}$, the highest number of tillers $\mathrm{m}^{-2}$ was recorded in $70 \mathrm{~cm}$ beds with three plant rows. At 40 and 50 DAS, the tiller production in conventional method and $70 \mathrm{~cm}$ beds with both two and three rows were statistically identical. From 60 to 120 DAS, the $70 \mathrm{~cm}$ beds with three rows produced significantly the highest number of tillers $\mathrm{m}^{-2}$. This was the lowest in $90 \mathrm{~cm}$ beds with two rows. These tiller productions obviously matched up with the number of panicles $\mathrm{m}^{-2}$, and which might be contributed to the grain yield of corresponding method. The results also indicated that the bed planting with narrow beds were able to compensate the number of tillers $\mathrm{m}^{-2}$ for blank spaces between beds while the wider one did not. In every treatment the number of tillers $\mathrm{m}^{-2}$ increased very rapidly in early stages and reached to the highest at 50 DAS and then started declining due to death of some tillers and at later stages it became more or less stable, which indicated that the maximum tillering of wheat might be occurred in between 40 and 60 DAS.

\section{Leaf area index (LAI)}

In the first year, at 20 DAS, the highest LAI was recorded in the conventional method. At 30 DAS the highest LAI was found in $70 \mathrm{~cm}$ beds with three plant rows followed by $70 \mathrm{~cm}$ beds with two rows and conventional method (Fig.1). This trend was continued up to 90 DAS and at the later stages (100-110 DAS), $70 \mathrm{~cm}$ beds with both two and three rows gave similar LAI, which were higher than the conventional method and rest of the bed planting treatments. Among the bed planting treatments, the $70 \mathrm{~cm}$ beds irrespective of plant row resulted in the highest LAI and with the increase in width of beds, the LAI was decreased throughout the growing period. Three plant rows per bed produced higher LAI than two plant rows per bed under same width bed width, which might be due to higher number of tillers $\mathrm{m}^{-2}$. In the second year, the results showed very similar pattern to that of first year.

At early the stage of crop growth, the LAI increased rapidly and reached the maximum at 50 DAS for all the treatments. From 60 DAS, it started decreasing, which was continued up to the maturity. The narrow beds $(70 \mathrm{~cm})$ were able to produce LAI as much as conventional method or even higher than conventional method at mid to later stage of crop growth while the wider beds $(80$ and $90 \mathrm{~cm}$ ) failed to do so. At maturity stage (110 DAS), the crop was greener in bed planting, especially in narrow beds, than conventional method resulting higher LAI, while it was sharply decreased in conventional method.

Simple linear regression analysis of LAI at different growth stages with grain yield of wheat showed that the relationship was significant in both the years (Fig. 2). However, the value of coefficient of determination at CRI stage (20 DAS) was low $\left(\mathrm{R}^{2}=0.23-0.44\right)$. The significant linear relationship of the LAI at heading (50 DAS), grain filling (80 DAS) and ripening (110 DAS) stages with grain yield $\left(R^{2}=\right.$ 0.59-0.88) indicated that the grain yield was increased with increasing LAI. Therefore, the higher LAI in bed planting with $70 \mathrm{~cm}$ bed at the later stages of crop growth might be a reason for higher grain yield.

\section{Dry matter production (DMP)}

Planting method significantly affected the DMP (shoot) of wheat at different DAS in both the years. In first year, at preliminary stage (20 DAS), the conventional and $70 \mathrm{~cm}$ beds with three rows produced similar dry matter yield, which was significantly higher than the rest of the treatments (Table 2). At 30 DAS $70 \mathrm{~cm}$ beds with both two and three rows, $80 \mathrm{~cm}$ beds with three rows and conventional method produced alike dry matter yield. This trend was continued up to 60 DAS. During 70 to 90 DAS, $70 \mathrm{~cm}$ beds with both two and three rows and conventional method recorded statistically similar DMP. From 100 to 120 DAS, $70 \mathrm{~cm}$ beds 

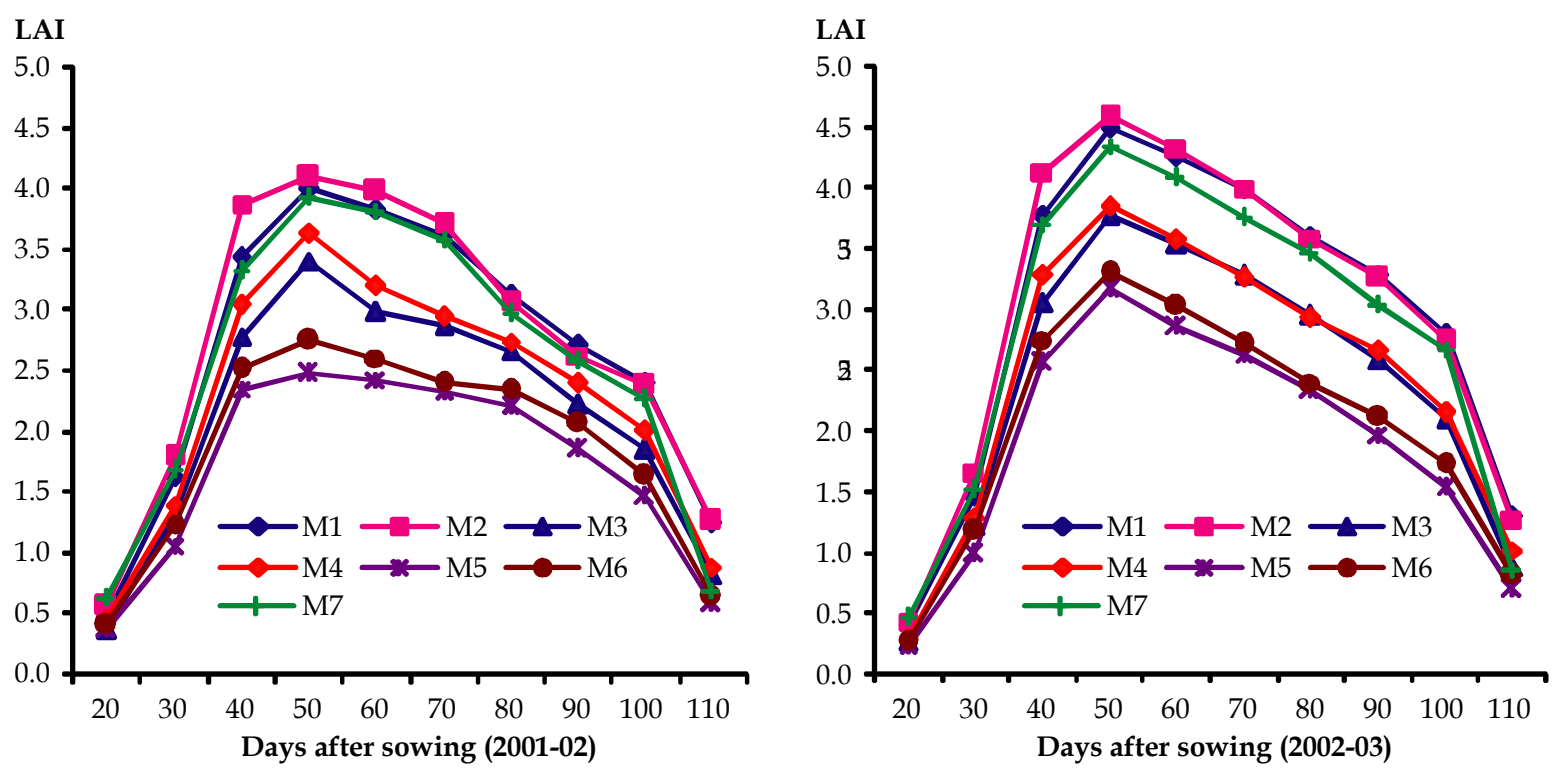

$\mathrm{M} 1=70 \mathrm{~cm}$ bed +2 rows, $\mathrm{M} 2=70 \mathrm{~cm}$ bed +3 rows, $\mathrm{M} 3=80 \mathrm{~cm}$ bed +2 rows, $\mathrm{M} 4=80 \mathrm{~cm}$ bed +3 rows, M $5=90 \mathrm{~cm}$ bed +2 rows, $\mathrm{M} 6=90 \mathrm{~cm}$ bed +3 rows, $\mathrm{M} 7=$ conventional

Fig. 1. Leaf area index of wheat under different methods of planting at different days after sowing.
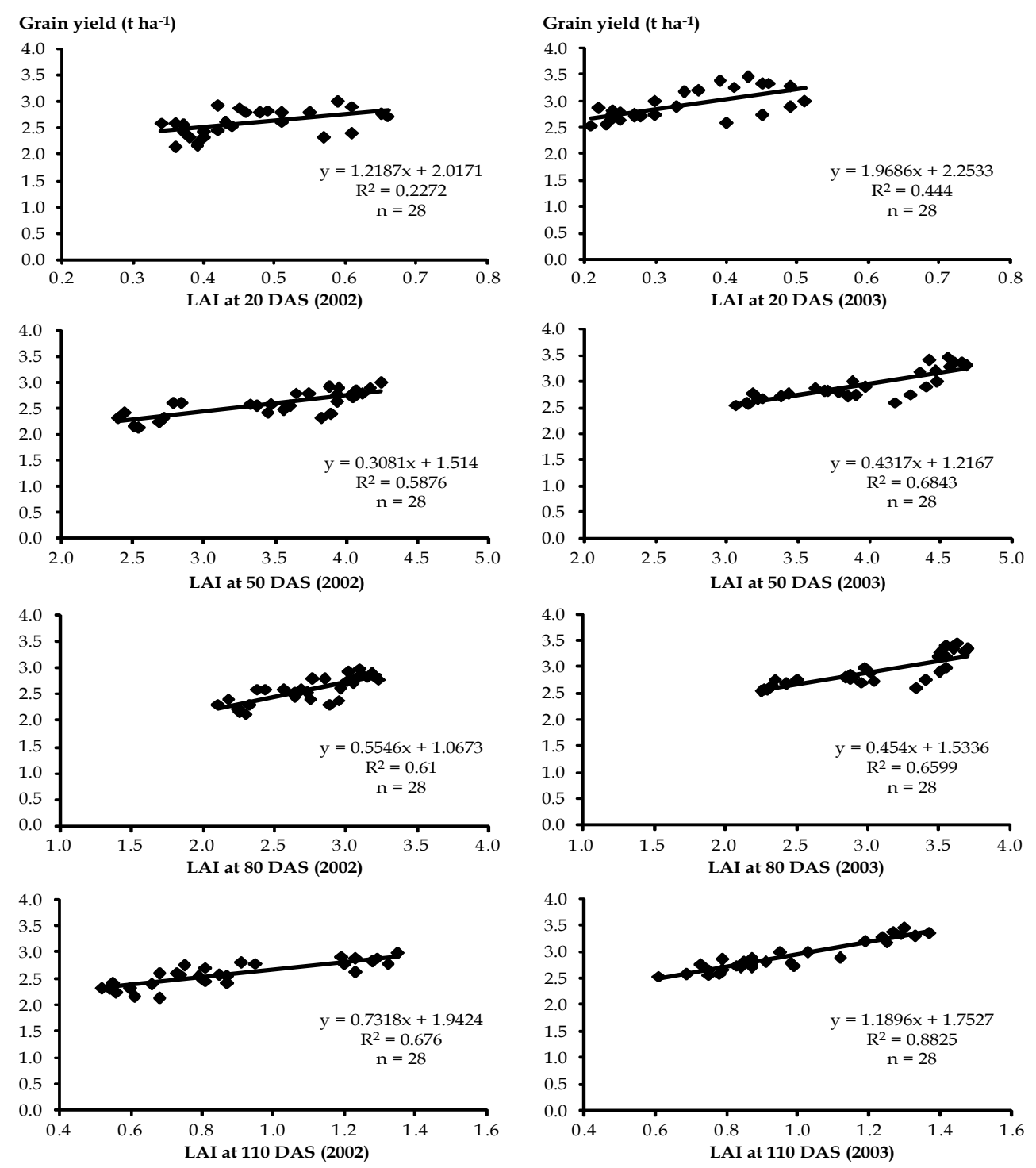

Fig. 2. The relationship between LAI at different stages of crop growth and grain yield of wheat. 

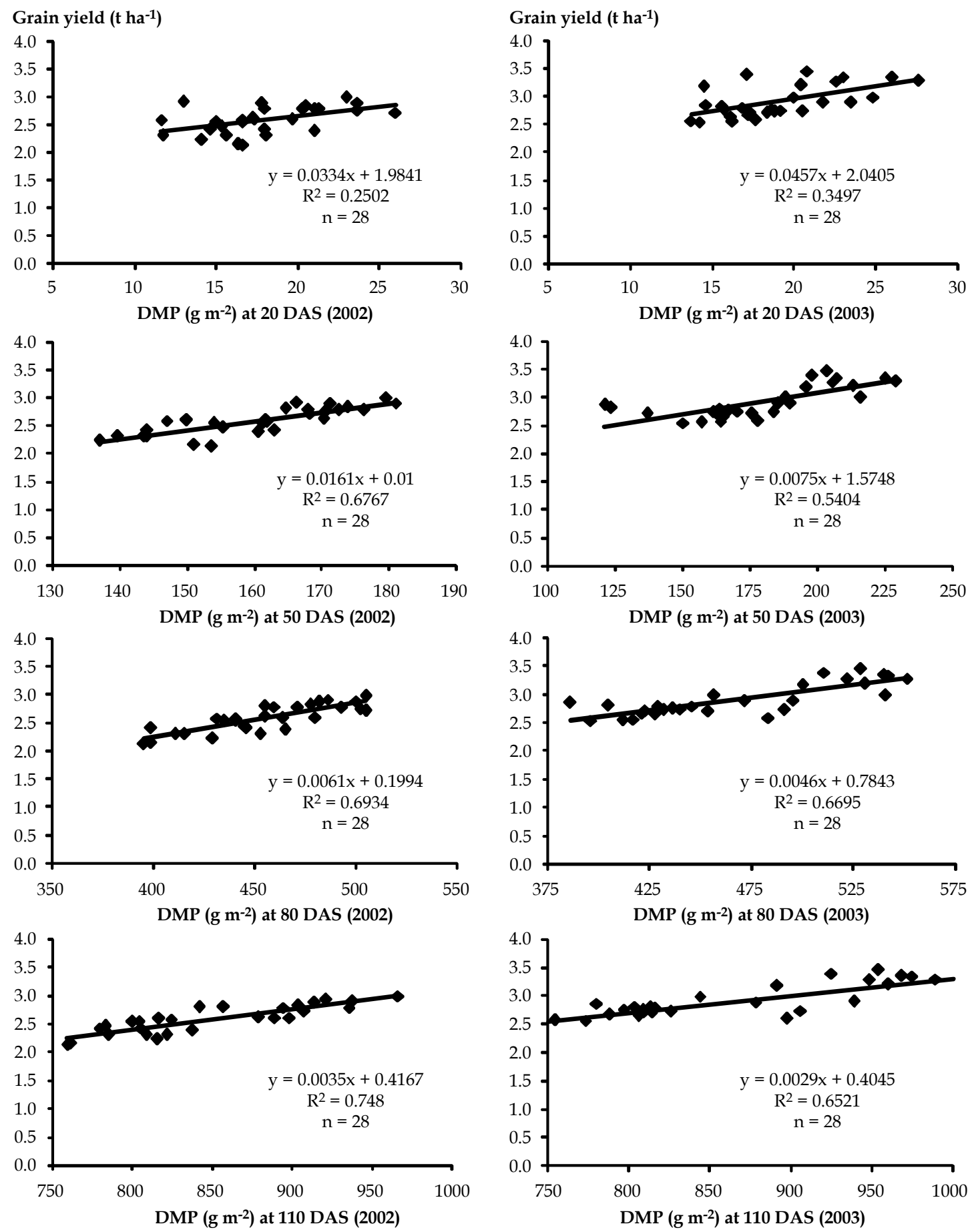

Fig. 3. The relationship between DMP at different stages of crop growth and grain yield of wheat.

with both two and three rows produced significantly higher dry matter yield than conventional method. Higher DMP of wheat under raised bed planting than conventional method was also reported by Khaleque et al. (2008). The similar pattern of DMP was observed in second year, in permanent beds.

Figure 3 illustrated simple linear regression analysis of DMP at CRI (20 DAS), heading (50
DAS), grain filling (80 DAS) and ripening (110 DAS) stages with grain yield of wheat. The relationship was significant in both the years. The linear relationship indicated that the grain yield was increased with increasing DMP. Therefore, the higher DMP in bed planting with $70 \mathrm{~cm}$ bed, especially at heading, grain filling and ripening stages might be a reason for higher grain yield $\left(R^{2}=0.54-0.75\right)$. 
Table 2. Dry matter production (DMP) of wheat under different planting methods at different days after seeding (DAS.

\begin{tabular}{|c|c|c|c|c|c|c|c|c|c|c|c|}
\hline \multirow[t]{2}{*}{ Planting method } & \multicolumn{11}{|c|}{ DMP $\left(\mathrm{g} \mathrm{m}^{-2}\right)$ at different DAS } \\
\hline & 20 & 30 & 40 & 50 & 60 & 70 & 80 & 90 & 100 & 110 & 120 \\
\hline & \multicolumn{11}{|c|}{$2001-02$} \\
\hline $70 \mathrm{~cm}$ bed +2 rows & $18 \mathrm{~b}$ & $51 \mathrm{abc}$ & $95 \mathrm{ab}$ & $171 \mathrm{ab}$ & $261 \mathrm{ab}$ & $363 a b$ & $479 \mathrm{a}$ & $607 a$ & 761ab & $908 \mathrm{a}$ & $977 \mathrm{~b}$ \\
\hline $70 \mathrm{~cm}$ bed +3 rows & $21 \mathrm{a}$ & $53 a$ & $97 \mathrm{a}$ & $177 \mathrm{a}$ & $265 a$ & $372 a$ & $488 \mathrm{a}$ & $611 a$ & $778 \mathrm{a}$ & $929 a$ & $1014 \mathrm{a}$ \\
\hline $80 \mathrm{~cm}$ bed +2 rows & $15 d$ & $49 \mathrm{~cd}$ & $89 \mathrm{bcd}$ & $157 \mathrm{bc}$ & $238 \mathrm{bcd}$ & $334 c$ & $438 b$ & $550 d$ & $699 d$ & $812 d$ & 867ef \\
\hline $80 \mathrm{~cm}$ bed +3 rows & $18 \mathrm{bc}$ & $51 \mathrm{ab}$ & $91 \mathrm{abc}$ & $162 \mathrm{abc}$ & $245 \mathrm{abc}$ & $342 b c$ & $450 b$ & $563 c d$ & $707 d$ & $820 \mathrm{~cd}$ & 885de \\
\hline $90 \mathrm{~cm}$ bed +2 rows & $15 d$ & $47 d$ & $85 d$ & $148 \mathrm{c}$ & $221 d$ & $304 d$ & $401 c$ & $507 e$ & $644 \mathrm{e}$ & $771 \mathrm{e}$ & $846 f$ \\
\hline $90 \mathrm{~cm}$ bed +3 rows & $17 \mathrm{c}$ & $49 \mathrm{bcd}$ & $86 \mathrm{~cd}$ & $147 \mathrm{c}$ & $226 \mathrm{~cd}$ & $331 c$ & $447 \mathrm{~b}$ & $580 \mathrm{bc}$ & $724 \mathrm{~cd}$ & $853 b c$ & $923 c$ \\
\hline \multirow[t]{2}{*}{ Conventional } & $22 \mathrm{a}$ & $52 \mathrm{ab}$ & $91 \mathrm{a}-\mathrm{d}$ & $161 \mathrm{abc}$ & $258 \mathrm{ab}$ & $366 a b$ & $481 \mathrm{a}$ & $600 \mathrm{ab}$ & $749 \mathrm{bc}$ & $868 b$ & $920 \mathrm{~cd}$ \\
\hline & \multicolumn{11}{|c|}{$2002-03$} \\
\hline $70 \mathrm{~cm}$ bed +2 rows & $19 \mathrm{~cd}$ & $62 b$ & $116 b$ & $201 b$ & $299 a b$ & $405 \mathrm{ab}$ & $520 \mathrm{ab}$ & 641ab & $796 a$ & $935 a$ & $1002 a$ \\
\hline $70 \mathrm{~cm}$ bed +3 rows & $24 a$ & $72 a$ & $130 \mathrm{a}$ & $218 \mathrm{a}$ & $314 a$ & $420 a$ & $536 a$ & $661 a$ & $821 a$ & $968 \mathrm{a}$ & $1034 a$ \\
\hline $80 \mathrm{~cm}$ bed +2 rows & 17de & $43 e$ & $77 \mathrm{e}$ & $136 \mathrm{e}$ & $218 \mathrm{e}$ & $309 e$ & $411 d$ & $523 d$ & $674 c$ & $805 c$ & $866 \mathrm{~d}$ \\
\hline $80 \mathrm{~cm}$ bed +3 rows & $19 \mathrm{bc}$ & $57 \mathrm{bc}$ & $107 \mathrm{c}$ & $176 \mathrm{c}$ & $258 \mathrm{c}$ & $349 c$ & $450 c$ & $560 c$ & $714 b$ & $838 b$ & $900 c$ \\
\hline $90 \mathrm{~cm}$ bed +2 rows & $15 \mathrm{e}$ & $49 \mathrm{~d}$ & $96 \mathrm{~d}$ & $162 d$ & $238 d$ & $324 \mathrm{de}$ & $417 \mathrm{~d}$ & $520 d$ & $659 c$ & $770 \mathrm{~d}$ & $828 \mathrm{e}$ \\
\hline $90 \mathrm{~cm}$ bed +3 rows & $18 \mathrm{cde}$ & $53 \mathrm{~cd}$ & $99 \mathrm{~cd}$ & $167 \mathrm{~cd}$ & $246 \mathrm{~cd}$ & $336 \mathrm{~cd}$ & $433 \mathrm{~cd}$ & $538 \mathrm{~cd}$ & $687 \mathrm{bc}$ & $801 \mathrm{~cd}$ & 853de \\
\hline Conventional & $22 \mathrm{ab}$ & $55 c$ & $107 \mathrm{c}$ & $191 b$ & $285 b$ & $388 b$ & $502 b$ & $628 b$ & $795 a$ & $936 a$ & $969 b$ \\
\hline
\end{tabular}

Figures in a column followed by different letters differ significantly at the $5 \%$ level by DMRT.

\section{Crop growth rate (CGR)}

In the first year, the bed planting in $70 \mathrm{~cm}$ bed with both two and three rows always resulted in higher CGR than conventional and other bed planting treatments (Fig. 4). The wider beds (80 and $90 \mathrm{~cm}$ ) gave lower CGR than conventional method except at very early and very later stages of crop growth, where conventional method gave the lowest. In the second year, during 20-30 DAS, the highest CGR was recorded in $70 \mathrm{~cm}$ beds with three rows, which was followed by the same bed width with two rows. However, CGR of these two treatments during 30-40 DAS were comparable. During 40-
50 to $100-110$ DAS, CGR in $70 \mathrm{~cm}$ beds with both two and three rows and conventional method were comparable. However, at the final stage (110-120 DAS) all the bed planting treatments resulted in higher CGR than conventional method. From the two years results it was revealed that the CGR in narrow beds $(70 \mathrm{~cm})$ was either comparable or higher than conventional method and in wider beds (80 and $90 \mathrm{~cm}$ ), it was lower in most of the cases. The CGR of different treatments correspond the grain yield of the respective treatments. 

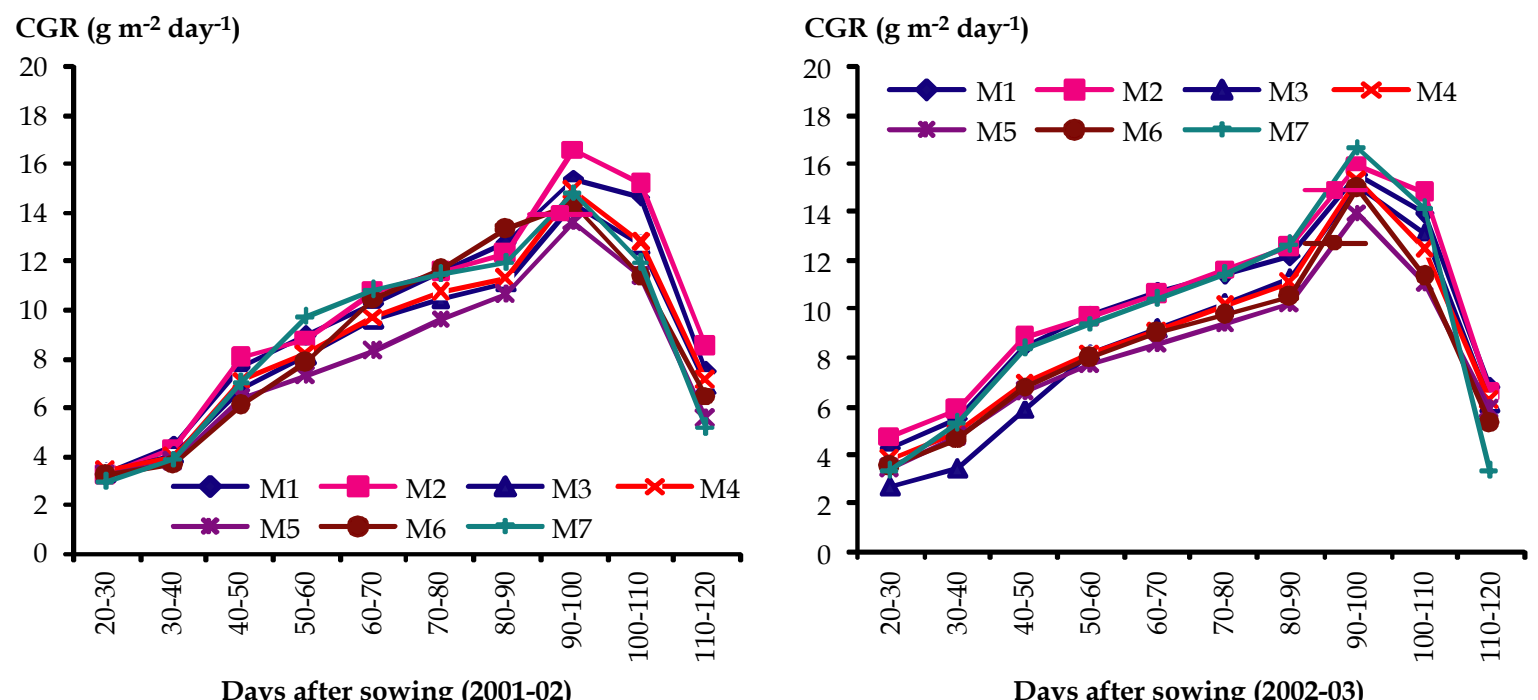

$\mathrm{M} 1=70 \mathrm{~cm}$ bed +2 rows, $\mathrm{M} 2=70 \mathrm{~cm}$ bed +3 rows, $\mathrm{M} 3=80 \mathrm{~cm}$ bed +2 rows, $\mathrm{M} 4=80 \mathrm{~cm}$ bed $+3 \mathrm{rows}, \mathrm{M} 5=90 \mathrm{~cm} \mathrm{bed}$ +2 rows, $\mathrm{M} 6=90 \mathrm{~cm}$ bed +3 rows, $\mathrm{M} 7=$ conventional

Fig. 4. Crop growth rate of wheat under different methods of planting at different days after sowing.

\section{Agronomic productivity}

The highest grain yield was recorded in $70 \mathrm{~cm}$ wide beds with two plant-rows bed ${ }^{-1}$, which was statistically equal with the grain yield of 70 $\mathrm{cm}$ wide beds with three plant-rows bed ${ }^{-1}$ and higher than conventional method and 80 and 90 $\mathrm{cm}$ wide beds with both two and three plant rows (Table 3). Similar results by bed planting in wheat was also reported by Dhillon et al. (2000), Gupta et al. (2000), Connor et al. (2003b), Sayre (2003), Hossain et al. (2004), and Meisner et al. (2005). Grain yield was higher in narrow bed $(70 \mathrm{~cm})$ and with the increase in bed width, yield was decreased. There was no significant yield difference between three and two plantrows bed ${ }^{-1}$. The highest yield in the bed planting with $70 \mathrm{~cm}$ beds were attributed to higher number of panicles $\mathrm{m}^{-2}$, grains panicle-1 and 1000-grain weight (Table 3). In spite of similar number of panicles $\mathrm{m}^{-2}$ in conventional and $70 \mathrm{~cm}$ bed, the grain yield of conventional method was lower due to lower number of grains panicle ${ }^{-1}$ and lower grain weight.

Table 3. Grain yield and yield components of wheat under different methods of planting.

\begin{tabular}{|c|c|c|c|c|c|c|c|c|}
\hline \multirow[b]{3}{*}{ Planting method } & \multicolumn{8}{|c|}{ Yield and yield components } \\
\hline & \multicolumn{4}{|c|}{$2001-02$} & \multicolumn{4}{|c|}{$2002-03$} \\
\hline & $\begin{array}{l}\text { Grain } \\
\text { yield } \\
\left(\mathrm{t} \mathrm{ha}^{-1}\right)\end{array}$ & $\begin{array}{c}\text { Panicle } \\
\mathrm{m}^{-2} \\
\text { (no.) }\end{array}$ & $\begin{array}{l}\text { Grain } \\
\text { panicle-1 } \\
\text { (no.) }\end{array}$ & $\begin{array}{l}\text { 1000- } \\
\text { grain } \\
\text { wt. (g) }\end{array}$ & $\begin{array}{l}\text { Grain } \\
\text { yield } \\
\left(\mathrm{t} \mathrm{ha}^{-1}\right)\end{array}$ & $\begin{array}{c}\text { Panicle } \\
\mathrm{m}^{-2} \\
\text { (no.) }\end{array}$ & $\begin{array}{l}\text { Grain } \\
\text { panicle-1 } \\
\text { (no.) }\end{array}$ & $\begin{array}{l}\text { 1000- } \\
\text { grain } \\
\text { wt. (g) }\end{array}$ \\
\hline $70 \mathrm{~cm}$ bed +2 rows & $2.85 \mathrm{a}$ & $306 a$ & $34.3 \mathrm{a}$ & $42 . .3 \mathrm{a}$ & $3.34 \mathrm{a}$ & $310 \mathrm{a}$ & $36.3 \mathrm{a}$ & $42.3 \mathrm{a}$ \\
\hline $70 \mathrm{~cm}$ bed +3 rows & $2.82 \mathrm{a}$ & $312 \mathrm{a}$ & $32.0 \mathrm{~b}$ & $41.7 \mathrm{a}$ & $3.28 \mathrm{a}$ & $325 a$ & $33.8 \mathrm{~b}$ & $41.9 \mathrm{a}$ \\
\hline $80 \mathrm{~cm}$ bed +2 rows & $2.54 \mathrm{bc}$ & $231 \mathrm{c}$ & $34.2 \mathrm{a}$ & $41.3 \mathrm{a}$ & $2.78 \mathrm{bc}$ & $260 c$ & $35.9 \mathrm{a}$ & $41.5 \mathrm{a}$ \\
\hline $80 \mathrm{~cm}$ bed +3 rows & $2.65 \mathrm{~b}$ & $244 \mathrm{~b}$ & $31.1 \mathrm{c}$ & $41.4 \mathrm{a}$ & $2.87 \mathrm{~b}$ & $282 \mathrm{~b}$ & $32.9 \mathrm{c}$ & $41.5 \mathrm{a}$ \\
\hline $90 \mathrm{~cm}$ bed +2 rows & $2.26 \mathrm{~d}$ & $219 c$ & $34.2 \mathrm{a}$ & $41.9 \mathrm{a}$ & $2.64 \mathrm{c}$ & $241 \mathrm{~d}$ & $36.0 \mathrm{a}$ & $42.1 \mathrm{a}$ \\
\hline $90 \mathrm{~cm}$ bed +3 rows & $2.43 c$ & $231 \mathrm{c}$ & $31.3 \mathrm{bc}$ & $41.5 \mathrm{a}$ & $2.67 \mathrm{bc}$ & $242 \mathrm{~d}$ & $33.0 \mathrm{c}$ & $41.7 \mathrm{a}$ \\
\hline Conventional & $2.35 \mathrm{dc}$ & $305 \mathrm{a}$ & $27.3 \mathrm{~d}$ & $39.2 \mathrm{~b}$ & $2.81 \mathrm{bc}$ & $274 \mathrm{bc}$ & $28.3 \mathrm{~d}$ & $39.6 \mathrm{~b}$ \\
\hline
\end{tabular}

Figures in a column followed by different letters differ significantly at the $5 \%$ level by DMRT 


\section{CONCLUSIONS}

In raised bed planting with narrow beds (70 $\mathrm{cm})$, different crop growth parameters such as total tiller production, LAI, DMP and CGR were similar or higher than conventional method at different growth stages of wheat. Agronomic productivity of wheat could be increased by bed planting with $70 \mathrm{~cm}$ bed in rice-wheat cropping system.

\section{REFERENCES}

Connor, D J, J Timsina and E Humphreys. 2003a. Prospects for permanent beds for the rice-wheat system. In: Improving productivity and sustainability of ricewheat systems: issues and impact. American Soc. Agron. Spec. Publ. 65:197210.

Connor, D J, R K Gupta, P R Hobbs and K D Sayre.2003b. Bed planting in rice-wheat systems. In: Addressing resource conservation issues in rice-wheat systems of South Asia: A resource book. Rice-wheat consortium for the Indo-Gangetic Plains. Intl. Maize and Wheat Impr. Cent., New Delhi, India. pp 103-108.

Dhillon, S S, P R Hobbs and J S Samra. 2000. Investigations on bed planting system as an alternative tillage and crop establishment practice for improving wheat yields sustainability. In: Proc. 15th Conf. of the Intl. Soil Tillage Res. Org. 2-7 July 2000. Fort Worth, Texas, USA.

Gupta, R K, P R Hobbs, M Salim, R K Malik, M R Varma, T P Pokharel, T C Thakur and J Tripathri. 2000. Research and extension issues for farm-level impact on the productivity on rice-wheat systems in the Indo-Gangetic Plains of India and Pakistan. Rice-wheat consortium Sem. Rep. Ser. 1.Rice-wheat consortium for the IndoGangetic Plains. New Delhi, India. 26 p.

Hobbs, P R. 2003. New tillage practice for South Asia: Plowing less to save water and slow global warming. In: Bed planting training course 2003. 19 May-21 Jun., 2003. Intl. Maize and Wheat Impr. Cent., Mexico D. F., 06600, Mexico.

Hobbs, P R and R K Gupta. 2003a. Resourceconserving technologies for wheat in the rice-wheat systems. In: Improving productivity and sustainability of rice- wheat systems: Issues and impact. American Soc. Agron. Spec. Publ. 65:149171.

Hobbs, P R and R K Gupta. 2003b. Rice-wheat cropping systems in Indo-Gangetic Plains: Issues of water productivity in relation to new resource-conserving technologies. In: Kijne et al. (ed.) Water productivity in agriculture: Limits and opportunities for improvement. pp. 239-253.

Hobbs, P R, R K Gupta, K D Sayre and T Friedrich. 2001. Technical issues for resource conserving technologies in Asia. Presented in Intl. Workshop on conservation agriculture for food security and environment protection in rice-wheat cropping systems. 6-9 Feb. 2001. Lahore, Pakistan.

Hossain, M I, C Meisner, J M Duxbury, J G Lauren, M M Rahman, M M Meer and M H Rashid. 2004. Use of raised beds for increasing wheat production in rice-wheat cropping systems. New directions for a diverse planet. Presented in 4th Intl. Crop Sci. Cong. 26 Sep. - 1 Oct. 2004. Brisbane, Australia.

Khaleque, M A, N K Paul and C A Meisner. 2008. Growth and yield of modern wheat (Triticum aestivum L.) varieties as influenced by raised bed seeding and nitrogen application. Bangladesh J. Agri. 33(2):15-21.

Malik, R K, G Gill and P R Hobbs.1998. Herbicide resistance: A major issue for sustaining wheat productivity in rice-wheat cropping systems in the

Indo-Gangetic Plains. Rice-wheat consortium paper Ser. 3. Rice-wheat consortium for the Indo-Gangetic Plains. New Delhi, India.

Meisner, C A, E Acevedo, D Flores, K D Sayre, I. Ortiz-Monasterio, D Byerlee and A Limon. 1992. Wheat production and growers practices in the Yaqui Valley, Sonora, Mexico. Wheat Spec. Rep. 6.Intl. Maize and Wheat Impr. Cent. Mexico.

Meisner, C A, H M Talukdar, I Hossain, M Gill, H M Rahmen, E Baksh, S Justice and K D Sayre. 2005. Introduction and implementing a permanent bed system in the rice-wheat cropping pattern in Bangladesh and Pakistan. Presented in ACIAR workshop on permanent bed planting systems. 1-3 Mar 2005. Griffith, NSW, Australia. 
Moreno, O, M Salazar and Martinez.1993.Tecnologiapara $\mathrm{J}$ produccion de trigo en surcos. Foll. Tecn. 22. SARH, INIFAP, cd. Obregon, Sonora, Mexico. [Ortega-

Limon, A, K D Sayre and C A Francis. 2000. Wheat and maize yields in response to straw management and nitrogen under a bed planting system. Agron, J. 92:295-302].
Sayre, K D. 2003.Raised bed system of cultivation. In: Bed planting training course. 19 May-21 Jun 2003. Intl. Maize and Wheat Impr. Cent. Mexico.

Yoshida, S, D A Forno, J H Cock and K A Gomez. 1976. Laboratory manual for physiological studies of rice. 3rd Edn. Intl. Rice Res. Inst. Philippines.83 p. 